\title{
Library Spaces for Urban, Diverse Commuter Students: A Participatory Action Research Project
}

\section{Margaret S. Brown-Sica}

\begin{abstract}
A data-gathering project using elements of Participatory Action Research was conducted at the Auraria Library, which serves the University of Colorado Denver, the Metropolitan State College of Denver and the Community College of Denver. The project was administered in order to shape a plan to develop a Learning Commons environment at the library. The researcher thought that the needs on a campus with many non-traditional, commuter students might differ from the needs of a more traditional college campus. Information was gathered using surveys, spontaneous focus groups, flipcharts and observation. Results were used and interpreted by students in an architecture class.
\end{abstract}

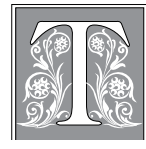

he Auraria Library serves three institutions of higher education: the Community College of Denver (which offers two-year vocational degrees), Metropolitan State College of Denver (which enrolls undergraduates), and the University of Colorado Denver (which offers both graduate and undergraduate programs). The library is one of the few places that bring all 50,000 students together on the shared urban campus, in which institutions occupy separate "neighborhoods." Separation is further encouraged by increasing ethnic and international diversity, accomplished without an accompanying enrollment management program and student services support. A significant portion of the student body is made up of firstgeneration college students as well as nontraditionally aged students-grandmothers and veterans - and a substantial percentage of disabled students. On this 99 percent commuter campus, most students have other responsibilities, such as work and families, that must be balanced with their school work, making time and money common concerns.

In response to these unique campus demographics, the 2008-2011 Auraria Library Strategic Plan placed a high priority on making e-resources readily available through the Web site, in recognition that many students come to class on campus and then complete assignments off campus as their schedules permit. In a companion initiative, because of the "digital divide" experienced by many students who lack computers with Internet access at home, the plan also placed a high priority on establishing a "learning commons"

Margaret S. Brown-Sica is Associate Director for Technology Strategy and Learning Spaces and Assistant Professor in Auraria Library at University of Colorado Denver; e-mail: Margaret.brown-sica@ucdenver. edu. (C) 2012 Margaret S. Brown-Sica, Attribution-NonCommercial (http://creativecommons.org/licenses/ $b y-n c-s a / 3.0 /)$ CC BY-NC 
for the more than 6,000 visitors who enter the library on a typical weekday. Because planning at the Auraria Library emphasizes evidence-based decision making, a multiphase plan was designed to gather data to inform the learning spaces project.

The researchers also hoped that the outcomes would help gain support for library renovation from campus stakeholders and donors. The recession presented challenges in regard to gaining approval and funds for library renovation. When a senior administrator visited the library, he emphasized that, although the budget was very strained at the present, this was a great time to plan. He said that departments who have gathered evidence and developed plans would be the first in line when more funds become available. This idea mirrors a sentiment in the article "2010 Top Ten Trends in Academic Libraries: A Review of the Current Literature," which states that "Increasingly, academic libraries are required to demonstrate the value they provide to their clientele and institutions. This trend is part of a broader accountability movement within higher education, resulting from demands from federal and state governments, accrediting bodies, employers, parents, and taxpayers for institutions to show the value of a college education and results of student learning outcomes." 1

Participatory Action Research (PAR) was selected as the most appropriate methodology. This action-oriented approach promotes the very learning that it intends to further in reinvented library facilities. In particular, collaborative inquiry processes foster self-evaluation, engage participatory problem solving, and advance professional development. Therefore, PAR represents a distinctive social science research approach which is:

- Practical. The results and insights gained from the research are not only of theoretical importance-and therefore advance knowledge in the field-but also lead to practical improvements during and after the research process.

- Participatory and collaborative.
The researchers are coworkers conducting research with and for the people concerned with the practical problem and its actual improvement-not an expert studying "subjects."

- Emancipatory. The relationships among coresearchers are egalitarian rather than hierarchical, because all participants are assumed to be participating equally to the inquiry.

- Interpretive. Social inquiry is assumed to generate "solutions" based on the views and interpretations of the people involved in the inquiry - rather than on positivistic notions of right or wrong answers. ${ }^{2}$

The methodology was therefore conducive to both developing relationships across the highly fragmented campus and "using information to learn" throughout the design and planning process. ${ }^{3}$ The research project aimed to advance the library mission to "Engage your mind. Enrich your future." Therefore, planning activities involved campus constituencies, including senior academic leadership at the provost and vice chancellor level, senior and middle management in student support services, elected officers of student governance assemblies and committees, campus master planners, and academic deans and directors.

In addition, building on project success elsewhere, such as at San Jose State University and California Polytechnic University, which involved students enrolled in academic courses in library design initiatives, members of two architectural studio classes generated recommendations for library staff consideration. ${ }^{4}$ Their investigations focused on two main questions: "What types of physical environment, technology, and services are needed to support and enhance the learning and research experience of the Auraria Library community?" and "How could the Library involve campus students, faculty, staff, and administrators in co-creating the (re)design concept?" 5 These guiding questions provided ample opportunities to pursue the larger question of "What 
is a library?" as well as more granular questions. The project culminated in "charette" which brought together stakeholders such as architects, university administration, library employees, campus planners, campus faculty and staff to identify plans for library renovation based on this research. The word "charette" refers to a consensus process in which a diverse group of people, designers, clients, and other stakeholders draft solutions to design challenges.

The PAR process advanced understanding through iterative review processes, involving significant numbers of both library and campus stakeholders. In doing so, the researchers avoided the space planning situation at other academic library, which at first did not include library users in the change planning process such as the process documented in the article "If at First You Don't Succeed... Creative Transformation at a Small Academic College." As Johnson writes:

In retrospect, it is easy to see why the changes did not work. For the most part, the changes were ones the library staff wished to see, not changes that reflected cosmetic remodeling ideas that students themselves might have selected. Also, although staff had gotten input from students, that input apparently was not specific enough. Staff realized that students agreed with their ideas but, it seems, interpreted them differently and expected them to result in structural changes, not aesthetic ones. Finally, as staff members were to learn, the changes did not address a fundamental shift in the way students were using the library and technology. ${ }^{6}$

The Auraria Library researchers and planners wanted to avoid making similar mistakes, and therefore used Participatory Action Research to avoid library-centered rather than user-centered decisions. In addition, Auraria researchers believed that higher education is changing, especially in relation to teaching methods. They explored these changes in conversation with teaching faculty and instructional designers. Insights corroborated current library research. For instance, Thomas Sens offers "twelve keys to library design: improving the academic experience," including three keys:

1. Create a sense of space. Today's libraries serve multiple roles on college campuses. Each comes with its own design opportunities: first, design spaces that promote group study and collaboration, which is critical to student success, then provide individual, quiet, contemplative spaces that blend the formal and informal to suit the divergent learning styles of each individual. To achieve this goal, the learning spaces committee chose to focus on creating specialty spaces including cafes, lounges, and meeting places for student activities.

2. Invite students to the table (and, we would argue, other stakeholders as well). Capturing the student perspective is critical in planning a successful library. Encourage students to participate in town hall-style meetings, focus groups, and advisory councils, or engage a student representative to join the planning committee to fully grasp student needs and expectations and what they would like to experience as end users. Bring into the discussion other end-user groups such as faculty, library staff, and IT personnel who can share their perspectives for a fuller understanding of how the library is to be designed.

3. Design for collaboration. Collaboration has changed nearly every facet of pedagogy and, therefore, every aspect of design. Students are encouraged to discover and share knowledge with other students while professors assist in this collaborative discovery process. The pedagogical paradigm has shifted from a "sage on the stage" to a "guide on the side." This new approach to learning and teaching requires spaces that promote group interaction and discussion. Con- 
sider breakout areas, group study rooms, and videoconferencing spots to allow for the healthy cross-fertilization of ideas. ${ }^{7}$

\section{Participatory Action Research}

Definitions of Participatory Action Research (PAR) commonly state that the subjects of the study perform some of the research and/or interpret the data themselves, with the aim of learning from the process to generate evidence to improve an existing problem. The people on whom the research is based are referred to as "participants" ${ }^{8}$ rather than "subjects." The research can involve people of any age or profession. For example, researcher Alice McIntyre reports on her PAR experiences of guiding 9- and 10-year-old Latina participants to explore "what it means for them to be girls." ${ }^{\prime \prime}$ Another essential element of PAR is its cyclical nature. Researchers and participants work through stages of "exploration, knowledge construction, and action at different moments throughout the research process." ${ }^{10}$

PAR grew out of "action research" developed at the end of World War II. Since then, it has been continuously shaped by social science researchers investigating a wide variety of arenas, including "civil rights and anti-racism movements, feminism, community development, and so on."11 According to Reason and Bradbury, action research:

- is a set of practices that responds to people's desire to act creatively in the face of practical and often pressing issues in their lives in organizations and communities;

- calls for engagement with people in collaborative relationships, opening new "communicative spaces" in which dialogue and development can flourish;

- draws on many ways of knowing, both in the evidence that is generated in inquiry and its expression in diverse forms of presentation as well as sharing learning with wider audiences;

- is values oriented, seeking to address issues of significance concerning the flourishing of human persons, their communities, and the wider ecology in which we participate;

- is a living, emergent process that cannot be predetermined but changes and develops as those engaged deepen their understanding of the issues to be addressed and develop their capacity as coinquirers both individually and collectively. ${ }^{12}$

\section{PAR in Libraries}

Inspiration for the research came from collaborative and stakeholder-developed studies at the University of Rochester, ${ }^{13}$ California Polytechnic State University, ${ }^{14}$ and Carleton College. ${ }^{15}$ The Rochester study used an anthropological approach to studying student needs and behavior in the library. The Auraria study used multiple methods like the Rochester study to gather information from different library experiences, such as being observed, working in a group, or responding to a survey to give a more " 360 " view of library needs. The Carleton College project studied how students use visual materials in their studies. Researchers there used flipchart data and gathered information from faculty and students while they worked on projects to follow how the users incorporated these materials. The idea of getting close to the students while they were actually working on a project influenced the Auraria group study survey/focus groups.

The California Polytechnic State University study engaged students in humancomputer interaction, technical writing, and new media courses to generate recommendations for new library systems, services, and programs. The California Polytechnic State University use of focus groups and interest in "learning communities" led to the Auraria Library's use of focus groups, influencing some of the questions regarding how library users work in groups. An important nonlibrary influence was the "Learning Landscapes Project." ${ }^{16}$ In this partnership between the University of Colorado Denver College of Architecture and Planning and Denver 
Public Schools, information was gathered from the community and students to build playgrounds that encourage learning and physical activity. This showed the Auraria groups that PAR can help gather information that can make a physical place more useful.

In recent years, libraries have increasingly employed inclusive and innovative methods to gather information for library decision making. Some of these studies have also intentionally engaged subjects in data interpretation and presentation. In "Collaborative Design: A LearnerCentered Library Planning Approach," Somerville and Collins present user-centered approaches for (re)designing library spaces at California Polytechnic State University and San José State University. ${ }^{17}$ These studies included student-generated research projects as part of class projects, which informed design of a new learning commons. Administration of EDUCAUSE Learning Spaces Tool surveys included distributing disposable cameras to take pictures of, for example, favorite places to meet others to work together. In both instances, students were involved in research project design and implementation, as well as data interpretation and presentation. When implementation decisions were subsequently based on student recommendations, students were then invited to evaluate the facilities' changes. This reflects a small but growing interest in PAR in library research.

PAR has been used more widely in $\mathrm{K}-12$ settings than in public or college libraries. This could be because of the popularity of the method in the social sciences such as education. An example is in the article "Creation of a Research Community in a K-12 School System Using Action Research and Evidence Based Practice." ${ }^{18}$ In this article, the authors used action research to ensure that students were ethical users of ideas and information. The authors had success using the method to move the library information use and instruction curriculum to an evidence-based model that addressed specific gaps in student understanding such as correct citing methods among middle school students.

\section{Learning Commons}

Elements of the learning commons developed in an iterative fashion, as "decision makers," "researchers," and "end users," considered data findings, using this agreed-upon framework for reflection and dialogue:

1. Check each wish list item against:

- the mission of the library and each institution; and

- the perceptions of the "decision makers" category of stakeholders.

2. Organize into "immediate priority" and "the tomorrow file."

Consider whether it is the library's mission to actually provide a particular service/technology OR a container/space for that service/technology to be made available.

3. Consider having a smaller number of options (services, technologies, equipment, and so on) and have them working well, reliably, and sustainably rather than a lot of new initiatives that cannot be maintained with the current level of staffing.

Data were generated from the following research methods:

1. Service desk journals. Blank journals would be placed at the service desks. People working at the desk would jot down observations and user comments. This information would be documented and analyzed. Four notebooks were partially filled for a total of about 30 pages of comments.

2. "Sandbox" project. This consisted of an area in which different types of furniture and technology were put and the use of these things was observed. These observations were listed in the journals above.

3. Flip chart information. Large flip charts were placed around the library with an opening sentence such as: What I would like to see in the library.... Six large charts were filled. 
4. Web survey. This was linked from the library homepage. On a few occasions, a librarian set up several computers and paper surveys near the front door of the library. Users were recruited as they came in with several possible rewards for filling out a survey such as candy bars, drinks, and small office supplies. Chocolate bars were by far the best recruiting tool. There was no incentive to take the survey via the Web site. The survey had questions that covered general user preferences for a library environment and services. A total of 374 responses were received on this survey.

5. Spontaneous focus groups. People working in a group in the library were approached by a library employee and asked several questions. This survey was also sent to people who had recently booked a group study room. While the number of surveys or focus groups was small (38), most of the surveys were administered to groups that consisted of $3+$ people.

6. Continuing activities that were not initially planned at the beginning of the study: two architecture classes based on "reinventing the library" in the University of Colorado School of Architecture and Planning and a two-day charette involving many stakeholders to come up with ideas for renovating the library.

Survey information was gathered and analyzed in the Web survey instrument Zoomerang. Qualitative answers were hand-tagged by using Zoomerang to assign words and comments to subject areas. Flip chart information was put into Zoomerang in text and analyzed with the same tagging procedure, as was the observation journal information. An external statistician was hired using a University of Colorado Denver faculty development grant to review analysis and provide additional analysis.

Throughout, the emphasis was on using research for action and using information to learn. As a consequence, when a two-day charette was conducted in fall semester 2010, there was a consistent vision among the campus participants, ${ }^{19}$ who determined that Phase One of the firstfloor remodel would restore the architect's original vision of "main streets" with "storefronts" for service points and consolidated staff workspaces to encourage synergy and collaboration. In response to student survey results vetted in campus conversations among administrators, faculty, staff, and students, an enlarged "tenant-built" café was included in the charette recommendations as well. See Appendix A for a list of Phase 1 initiatives.

\section{Results: Environment Furniture}

In the Web survey, pictures were shown to illustrate several types of furniture. Users were able to rate the furniture from 1 (least preferred) to 10 (most preferred). Respondents did not have to rank the choices and could have chosen any number for any option. As can be seen in table 1, many of the kinds of furniture hover around the 50 percent approval rate. These are: "Soft Furniture," "Group Study Furniture," and "Booths." Flexible and Modular furniture were rated lower. It appears that there are not strong preferences in this area, except toward furniture that is relatively traditional. In the observation journals, furniture improvement is mentioned in 6 percent of all entries. In response to the question, "If there was one thing you could change about the first floor of the library, it would be..." users mentioned furniture 25 percent of the time. In the employee survey, five out of twenty-four respondents mentioned furniture as a good way to improve the library environment.

During the research project, several furniture companies allowed the Auraria Library to test out different items. Observations were then noted in the service desk journals. By far the most popular item was the MediaScape by Steelcase. This includes a table, chairs, two large monitors, and wiring and KVM switch that allow users to plug in laptops and switch monitor displays between sev- 
eral laptops. Furniture improvement is a strong theme, but there does not seem to be a strong preference for a certain type of furniture. The continued interest in traditional library furniture, desks and chairs, and the interest in the MediaScape seems to reflect our commuter students' need to "get down to work" as opposed to socializing. It might be interesting in the future to ask which kind of furniture is best for specific activities.

\section{Electricity/Outlets/WiFi}

The library cannot add more electrical outlets without a major electrical upgrade. However, the data support that this upgrade would be one of the best investments that could be made. In table 1,25 percent of the respondents stated that more computers would be the most important change in the library (which is not possible without the upgrade) and 12 percent believe that more outlets are the most important improvement that could be made to the first floor. The information from the Web survey (Question 2) places laptop ownership at 88 percent. This statistic alone indicates that, to make sure library users are supported, the library needs to have laptop outlets widely available and excellent wireless service. Responses to a question regarding which services would be desirable in the library, "Electrical Outlets" were important to 73 percent of those surveyed. In the Group Study survey, "Electrical Outlets" are documented as the most desirable attribute in a group study area. This shows an overwhelming need for extended electrical infrastructure in the building.

\section{More Room and Noise}

The Auraria Library is a small building for such a large student body. It has two floors and 145,657 assignable square feet. There is a theme in the data that advocate for a larger library. In table 1, users requested a "More Space/Bigger Library" 13 percent of the time. Noise is a consistent theme in several areas of the data collected. Web survey question number 4 (What

\begin{tabular}{|l|c|}
\hline \multicolumn{2}{|c|}{ WABLE 1 } \\
Open Ended Question: If there was one \\
thing you could change about the 1st \\
floor of the library it would be... \\
\hline Changes & Percentage \\
\hline (More) Computers & $25 \%$ \\
\hline More/Better Furniture & $25 \%$ \\
\hline More Attractive Environment & $14 \%$ \\
\hline More Space/Bigger Library & $13 \%$ \\
\hline Electrical Outlets & $12 \%$ \\
\hline Less Noise & $11 \%$ \\
\hline Closed Study Rooms & $10 \%$ \\
\hline More Food/Drink Options & $8 \%$ \\
\hline Community User Complaints & $5 \%$ \\
\hline Improve Printing & $4 \%$ \\
\hline Improve Navigation & $3 \%$ \\
\hline Make the Library Cleaner & $3 \%$ \\
\hline Improve Entrance & $3 \%$ \\
\hline Build More Bathrooms & $3 \%$ \\
\hline Improve Lighting & $2 \%$ \\
\hline Be Open More Hours & $1 \%$ \\
\hline Better WiFi & $1 \%$ \\
\hline
\end{tabular}

Would Help Users Achieve Their Learning, Classwork and Research Goals in the Library?), noise issues are mentioned 13 percent of the time also. Those surveyed in the Web survey regarding their favorite place to study, "Less Noise" was the most often mentioned reason for location choice.

\section{Selected Comments}

Sometimes actual quotes are more informative than percentages. Select comments from users regarding the library environment from the surveys and flip charts:

- Update the bathrooms

- Hard to accomplish but to remind visitors to use their library voices

- Vending machines that stock healthy, inexpensive foods \& take debit or credit cards.

- Better ability to scan/electronically 
retrieve articles only available in print in the library

- Have some tutors

- Camera checkout/movie rental/ better computers

- Colors: it's dreary!

\section{Results: Technology}

In the Web survey, users were asked about the technology respondents use on a regular basis. This was asked to help shed light on what kinds of technology the library should support. When comparing these results to the ECAR Study of Undergraduate Students and Information Technology, $2009,{ }^{20}$ the percentage of laptop ownership is almost the same: 88 percent. However, the use of Internet-capable phones is higher in the ECAR study (33.6\% vs. $21 \%$ in the Auraria study). Of those who use a laptop, over 80 percent also use a cell phone, Internet-capable phone, or PDA. In the Auraria study, those who use an Internet-capable phone are more likely to also use other technology, such as scanners, audio devices, and video equipment. The significant use of "E-book Readers" was of note at 12 percent. The task force wondered if students are often required to include audio or video content in their assignments and if the library should support this need. In table 2, Web Survey Question 9, students were asked about such assignments. More than one-third $(39 \%)$ reported that his was the case. If this many students need to manipulate digital media, the library needs to provide technology that supports this process including such items as sound recorders, video cameras, scanners, and editing software. Employees should also have knowledge of such tools. Table 2 also documents that 71 percent of those surveyed need to give presentations in class. Presentation practice areas would be another service that should be provided, along with any technology such as large monitors, projectors, and video recording equipment.

\section{Results: Services}

The results in table 3 are in response to the following Web survey question: "What types of services would be helpful in the library? Mark as many as apply." The data indicate that users desire a writing center, eating area, and tutoring. There is interest in being able to make a reservation for research help, which is remarkable because this service already exists. This indicates that it should be expanded and better publicized. Those who would like a writing center were significantly more likely to also want tutoring services. Other responses echo issues that have already been covered above. There are also documented needs for electrical outlets, scanning equipment, and presentation practice rooms. Other requests were: application help, a representative from each college IT department, and the ability to reserve a computer, which also indicates that there are not enough computers. The

\begin{tabular}{|l|c|}
\hline \multicolumn{2}{|c|}{ TABLE 2 } \\
Web Survey Question 9 \\
Do any of your assignments require the following? \\
\hline Attribute & Percentage \\
\hline Audio or video/visual resources incorporated in your assignments & $39 \%$ \\
\hline The use of citation software (such as Zotero, Endnote, etc.) & $32 \%$ \\
\hline Group work or study & $73 \%$ \\
\hline The use of social applications such as wikis, blogs, etc. & $24 \%$ \\
\hline Statistical analysis & $32 \%$ \\
\hline Presentations & $71 \%$ \\
\hline Other & $9 \%$ \\
\hline
\end{tabular}


need for the ability to reserve a computer may be a specific need on an urban commuter campus where many students are paying for parking or need to get their research done at a specific time so that they can get to work or back to a family.

The library currently has a coffee cart that takes only cash. There isn't really any furniture/environment specifically designed for eating. However, it is common to see a student sitting on the floor eating a sand wich brought from home. This may reflect demographics of the campus, which includes many students who are from low economic backgrounds and/or are working to support their studies. Concerns about cleaning up food waste, both now and in the future, came up numerous times in various response sections. In the group survey, there was no specific question on food options. However, 29 percent of respondents mentioned coffee shops as a preferred study location. Both ambiance and beverages were mentioned as reasons.

On Web Survey Question 4, which asked about food offerings (free re-

\begin{tabular}{|l|c|}
\hline \multicolumn{2}{|c|}{ TABLE 4} \\
Web Survey Question 3 \\
$\begin{array}{l}\text { What kind of additional food/drink op- } \\
\text { tions would you like to see available in } \\
\text { the library? }\end{array}$ \\
\hline Choices & Percentage \\
\hline Vending Machine/Snacks & $23 \%$ \\
\hline Hot Beverages & $22 \%$ \\
\hline $\begin{array}{l}\text { Café Choices (Pizza, Burrito, } \\
\text { Smoothies) }\end{array}$ & $20 \%$ \\
\hline Cold Drinks & $17 \%$ \\
\hline $\begin{array}{l}\text { Prepackaged Sandwiches/ } \\
\text { Salads }\end{array}$ & $16 \%$ \\
\hline Fast Food & $9 \%$ \\
\hline
\end{tabular}

\section{TABLE 3 Web Survey Question 7}

What type of services would be helpful to have in the library? Mark as many as apply.

\begin{tabular}{|l|c|}
\hline Service & Percentage \\
\hline Laptop plug-ins (electrical outlets) & $73 \%$ \\
\hline Writing Center & $59 \%$ \\
\hline Eating Area & $54 \%$ \\
\hline Tutoring & $54 \%$ \\
\hline Reserve Research Help & $43 \%$ \\
\hline Scanning Station & $39 \%$ \\
\hline Computer Application Assistance & $38 \%$ \\
\hline Presentation Practice Room & $31 \%$ \\
\hline News and Weather Information Area & $29 \%$ \\
\hline Additional Software & $28 \%$ \\
\hline Representative from main IT Department & $25 \%$ \\
\hline Ability to Reserve a Computer & $24 \%$ \\
\hline Video Editing Equipment & $18 \%$ \\
\hline
\end{tabular}

sponse), 20 percent of the responses included the word "healthy." There were many requests for credit card or debit card options. A surprisingly large number of responses asked for no food options. Many of these specifically mentioned the large amount of food trash currently in the building. Many requested longer hours of food service. The interest in vending machines was higher than anticipated, but it should be noted that they are a common occurrence in most campus buildings. Nearly half ( $45 \%$ ) of all survey respondents were not interested in having an eating area in the library. Of these, the majority was simply not interested, and the remainder was concerned about the mess and noise level.

\section{Results: Group Work/Study Needs}

The Group Study Survey/Focus Groups concentrated on the issue of group work in the library. The total sample size of this survey was only 38 . The margin of error in the results may be high because of the small sample, but most samples reflected the consolidation of the opinions of $3+$ us- 
ers. However, despite the accuracy issues, the results are still of interest because of the high percentage $(73 \%)$ of users who do engage in group work (according to the Web survey) in the library and the great necessity for the library to do as much as possible to make this work productive.

\section{Demographics and Activities}

As seen in table 5, half of all survey respondents are between 25 and 40 years old. Sixty-nine percent of respondents are full-time students. One fourth of full-

\begin{tabular}{|l|c|}
\hline \multicolumn{2}{|c|}{ TABLE 5 } \\
Group Study Survey Question 1 \\
Who will be attending the group study \\
session? Pick all that apply. \\
\hline Attribute & Percentage \\
\hline Students & $92 \%$ \\
\hline Commuter Student & $69 \%$ \\
\hline Full-time Student & $58 \%$ \\
\hline Age 25-40 & $50 \%$ \\
\hline UCD Affiliation & $45 \%$ \\
\hline MSCD Affiliation & $34 \%$ \\
\hline Employed Full-time & $31 \%$ \\
\hline Age 18-25 & $28 \%$ \\
\hline Live with Parents & $22 \%$ \\
\hline Faculty & $21 \%$ \\
\hline Age 40-60 & $14 \%$ \\
\hline CCD Affiliation & $11 \%$ \\
\hline Parent with Young Kids & $11 \%$ \\
\hline Staff & $5 \%$ \\
\hline Dorm Resident & $3 \%$ \\
\hline
\end{tabular}

\begin{tabular}{|l|c|}
\hline \multicolumn{2}{|c|}{ TABLE 6 } \\
Group Study Survey Question 2 \\
What are you working on today? \\
\hline Activity & Percentage \\
\hline Studying & $74 \%$ \\
\hline Group Project & $53 \%$ \\
\hline Researching & $34 \%$ \\
\hline Meeting Tutor & $5 \%$ \\
\hline Rehearsing a Performance & $3 \%$ \\
\hline
\end{tabular}

time students are also employed full time. Although only 69 percent of the respondents classified themselves as commuters, the official figure is 99 percent (as noted earlier in this article). It indicates that the small population of dorm residents was disproportionately represented or that, although students don't live on campus, they may not identify as "commuters" for some reason. Fifty percent are between the ages of 25 and 40, and 31 percent are employed full time. Ten percent are parents with young children. The vast majority of groups were studying, and most of this work had to do with a group project. One group was using the area as a dramatic rehearsal area.

The results in table 7 were possibly among the most significant results in the study. The frequency of meeting for group work was much higher than anticipated. The fact that more than 40 percent of samples indicated meeting at least once a week and as much as three times per week is noteworthy. That the students on this campus are overwhelmingly commuters makes the importance of places to meet a priority for the library, as well as other campus buildings.

\section{Observation Journals and Flip Charts}

There were 152 entries in journals at the service desks from library employee observations or comments by library users. Entries were free form and less focused on the library environment than the information gathered in the surveys. Responses ranged from comments about the temperature in the library to information on the library Web site. Despite the

\begin{tabular}{|l|c|}
\hline \multicolumn{2}{|c|}{ TABLE 7 } \\
How Often Do Respondents Meet \\
to Work in Groups?
\end{tabular}




\begin{tabular}{|l|c|}
\hline \multicolumn{2}{|c|}{ TABLE 8 } \\
Where is the best place to meet and why? \\
\hline Location & Respondents \\
\hline Auraria Library & 20 \\
\hline Group Study Room & 14 \\
\hline First Floor of the Library & 6 \\
\hline Campus Classroom & 4 \\
\hline Student Union (Tivoli) & 4 \\
\hline Restaurant & 3 \\
\hline Why & Respondents \\
\hline Quiet & 7 \\
\hline Space to Spread Out & 6 \\
\hline Projector & 3 \\
\hline Central Location & 3 \\
\hline Whiteboards & 2 \\
\hline Computers & 2 \\
\hline
\end{tabular}

never take a survey or comment on problems. This issue of navigation and temperature were recognized as major issues due to this feedback. Some comments were:

- Patrons complained about its being "too hot" in the library. They were correct. It was very hot in the library this weekend.

- Midsized whiteboard is the most popular. Large board is used in the evening in the back as a wall. I suggest more midsized whiteboards.

- Students enjoy using headphones at computers for films.

- Students enjoy pulling chairs together to share stations, though many are happy with their own!

- Student commented on nice open space and asked if we will get more tables or computers.

The responses from the flip charts were somewhat random, which was expected from such an unstructured venue. The most common subjects for comments were:

- Group study rooms

- Problems with noncampusaffiliated users

- Electrical outlets

- Requests for more traditional desks

Some of the most interesting comments were:

- Academic research-only computers (no Facebook, YouTube, and the like)

- Smoking area

- More small desks or two-person tables to fit more people.

variety of information, some issues were commented on the most:

- "Computer issues" 26\%

- Study rooms $14 \%$

- Navigation $13 \%$

- $\quad$ Problems with printing 11\%.

The value of this type of information is in bringing up issues that are not mentioned on the surveys and the observation of issues from people who might

\section{Study Outcome Overview}

Overall, the stakeholders and users of the library on this diverse, largely commuter campus agreed on what they want in a library. They want a building environment that is comfortable, clean, quiet, and secure. They want services to support research such as writing centers, tutoring, and improved collections. They want services that are available when 
they are: research help by appointment, the ability to check out technology they may not own or don't want to bring to campus. They want things that directly support their curriculum: dynamic media editing stations, fully equipped presentation and group study areas, and furniture and technology that support group work. They want equipment like the following: technology such as laptops, video and still cameras, audio recorders and nontechnology items such as scientific calculators and whiteboards. The users seem to want practical, efficient services that align with the campus demographics. The following is an excerpt from the recommendations in the project's final report.

- Create high-quality group study areas, with and without walls; include several different kinds of options with such things as whiteboards, furniture, monitors, electrical outlets, and switches to change display from one computer to another.

- Provide online/mobile reservation options (that are easy to access) for research help, computer access, equipment, and study rooms. Try to make reservations available by mobile device so that students can make reservations, although they might not have access to a computer while commuting or on campus.

- Install larger and double monitors for use by groups or multimedia projects.

- Make sure that up-to-date information about services, software, and equipment is available online, in the library, and at the service desks.

- Improve navigation. Make sure users don't waste their time finding things.

- Install digital media editing applications on all the computers.

- Consider charging stations, lockers, monitors for laptops, and healthy, attractive food and eating areas.

- Consider services that "come to the users," such as paging, texting, or instant messaging help especially when computers are full.

- Make sure that the environment is hospitable. Cleanliness, security, and comfortable furniture should be taken into consideration.

\section{Interpretation of Data}

An important part of PAR is the interpretation of data by the people being studied. Throughout, researchers involved users in considering the decision-making implications of research results. For instance, an outreach effort to the University of Colorado Denver College of Architecture and Planning involved two courses in generating redesign recommendations for the $\mathrm{Au}-$ raria Library. The professor and students considered the diverse data sets and, in addition, met with library employees and master planners. They made mid-semester and final presentations to the entire library staff. While many of these projects were very esoteric and did not address all the data gathered, the class was a success in several ways. Campus planners from the three institutions on the Auraria Campus, the original planner of the Auraria campus who had worked with the architect, and several prominent local architects were recruited to address the class and serve as jurors for the mid and final semester reviews. The students raised their own money to travel to Chicago on spring break to see other buildings designed by the original architect, Helmut Jahn. As a result, the cause to renovate the library, long deferred, developed real campuswide support.

A tri-institutional planning committee was formed, and the charette was held to refine the design concept. The first phase of the project is scheduled to take place in the summer of 2011. Additional classes that have worked on projects based on the results of the information gathered are a Metropolitan State College of Denver Human Factors Engineering class and a senior civil engineering group from the University of Colorado Denver in the spring of 2011. Such initiatives place the library at the heart of student learning.

\section{Conclusion}

The benefits of using a Participatory Action Research approach were much 
greater than anticipated. For instance, while the data were interesting and illuminating to the Auraria Library researchers, the greater outcome was increased staff confidence in conducting research. As a consequence, decisions in the library are increasingly based on evidence. Strengthened connections with students and faculty in several de- partments predict sustainable learning partnerships. Evidence-based planning fortified by strong relationships with master planners and senior leaders at the three institutions predict support for Phase 2 initiatives as well. The library is now poised for both renovation and reinvention, which seemed an unattainable goal two years ago.

\section{Appendix A \\ Project Scope Notes}

\section{Phase 1 Project, AHEC Library}

\section{Staff Office Area}

The office area will consist of 10 enclosed offices, minimum, 32 modular work stations, and 10 smaller student work stations. The office layout should encourage collaboration. Increased opportunities for natural light should be explored.

Other functional areas to be included in this area are:

- 2 Conference Rooms (one large, one small).

- 2 Processing Areas for receiving and interlibrary loan holding and reserves and including 2 copiers/fax.

- Mail and receiving area.

- File cabinets both within the main office area and in a storage room.

- $\quad$ Break Room with kitchenette.

- 2 unisex rest rooms (optional).

Also, the office area should be designed for future expansion to accommodate distribution of media and reserves.

\section{Group Study Rooms}

6-14 rooms are desired. Some rooms may be built in later phases depending on project cost. Rooms should be high tech upgradable. Some rooms may be divisible into 2 separate study spaces.

\section{Café Preparation}

Food and beverage preparation will be restricted to coffee makers, microwaves, and other equipment that will not require hooded exhaust or fire suppression. The area will include a 3-compartment sink and electrical power for café appliances including refrigeration, microwave oven, dishwasher, and other appliances to be supplied by the vendor. Area for a dry storage room will be identified.

Seating will be at moveable tables that also serve as study areas with access to power outlets where possible. The open seating area will be flexible to accommodate lectures, presentations, and music. 
Rest room modification is not anticipated in this phase unless it is required from code review or to accommodate the design of the café.

\section{Temporary Reception /Help Desk}

The current front desk area needs to be expanded to accommodate research and technical assistance with shelving modifications to facilitate work flow. This work is expected to involve relatively minor modifications and to be accomplished with AHEC resources. Consequently, it will not be part of scope of the phase 1 project.

\section{Demolition}

Offices in the proposed café area will be demolished to create open seating area. Offices, including the art gallery, adjacent to the rest rooms (east side) will be demolished to create open seating and study area.

Office modifications in the future Visual Resource Center area are not part of the scope of this project. Offices areas on the 2 nd floor will become storage areas and will not be part of the scope of this project.

\section{Temporary Offices}

Staff currently occupying room 118 are anticipated to be temporarily accommodated in other existing library space; the scope of this project phase does not include provisions for equipping temporary office locations.

\section{Wayfinding}

The library staff would like to explore a design concept for wayfinding and signage that can be implemented in phases as renovation projects are undertaken.

\section{Furniture}

Interior design services for selection of office furniture and modular furniture are desirable to be included in the scope of the project. Furniture for public areas may be excluded from the project scope.

\section{Other A/E Services}

A concept design for the future Main Street Desk should be a part of the scope of design services. 


\section{Notes}

1. “2010 Top Ten Trends in Academic Libraries," College and Research Libraries News, 71 n. 6, available online at http://crln.acrl.org/content/71/6/286.full [accessed 27 January 2012].

2. O. Zuber-Skerritt, Action Research in Higher Education (London: Kogan Page Limited, 1992).

3. Christine Bruce, Informed Learning (Chicago: American Library Association, 2008).

4. Mary M. Somerville, Working Together: Collaborative Information Practices for Organizational Learning (Chicago: Association of College and Research Libraries, 2009).

5. Brown-Sica, Margaret, Karen Sobel, and Erika Rogers. 2010. "Participatory action research in learning commons design planning." New Library World 111 (7/8): 302-319. Available online at http://digitalcommons.calpoly.edu/cgi/viewcontent.cgi?article=1156\&context=csse_fac [accessed 27 January 2012].

6. Johnson, Rita. 2009. “If at First You don't Succeed...Creative Transformation at a Small Academic College," Technical Services Quarterly 26, no. 2:107-124.

7. T. Sens, "Twelve Keys to Library Design: Improving the Academic Experience," Library Journal 134, no. 9 (2009): 34 .

8. Alice McIntyre, Qualitative Research Methods Series 52: Participatory Action Research (Los Angeles: Sage, 2008), 1-79.

9. Ibid.

10. Ibid.

11. Ibid.

12. Peter Reason and Hilary Bradbury, "Introduction," in Sage Handbook of Action Research: Participative Inquiry and Practice, 2nd ed., eds. Peter Reason and Hilary Bradbury (Thousand Oaks, Calif.: Sage, 2008), 1-3.

13. N.F. Foster, S. Gibbons, Studying Students: The Undergraduate Research Project at the University of Rochester (Chicago: Association of College and Research Libraries, 2007).

14. Somerville, Mary N. and Navjit Brar, 2010. "From information to learning commons: campus planning highlights." New Library World 111, no 5/6: 179-188.

15. L. Nixon, H. Tompkins, and Paula Lackie, "Curricular Uses of Visual Materials: A Mixed Method Institutional Study," available online at http://apps.carleton.edu/curricular/support/ CUVMStudy/ [accessed 8 November 2009].

16. Bambi Yost, "Planning and Design for Healthy Child Development: Mapping Places of Play and Prey with Denver Kids" (Paper presented at the Rocky Mountain Land Use Institute Conference, March 2007, Denver, Colo), available online at http://bambilyost.com/Documents/ Yost\%202007\%20RMLUI\%20handout\%20-\%20mapping\%20with\%20kids.pdf [accessed 1 January 2011].

17. Somerville, Mary M., and Lynda Collins. 2008. “Collaborative design: a learner-centered library planning approach." Electronic Library no. 6:803-820.

18. Susan D. Ballard, Gail March, and Jean K. Sand, "Creation of a Research Community in a K-12 School System Using Action Research and Evidence Based Practice," Evidence Based Library and Information Practice 4 (2009): 2, available online at http://ejournals.library.ualberta.ca/index. php/EBLIP/article/view/5020/5319 [accessed 1 January 2011].

19. Somerville, Mary M., and Margaret Brown-Sica. 2011 "Library space planning: a participatory action research approach." Electronic Library 29, no 5:669-681.; Brown-Sica, Sobel, and Rogers, "Participatory Action Research in Learning Commons Design Planning."

20. Shannon D. Smith, Gail Salaway, and Judith Caruso, "The ECAR Study of Undergraduate Students and Information Technology, 2009," Educause Center for Applied Research, available online at www.educause.edu/Resources/TheECARStudyofUndergraduateStu/18725 [accessed 28 January 2012]. 


\section{ESSENTIAL SERIES FOR YOUR COLLECTION... FROM PETER LANG PUBLISHING}

\section{DIGITAL FORMATIONS}

EDITED BY STEVE JONES

NEW IN THIS SERIES:

THE MOBILE MEDIa READER

EDITED BY ANANDAM KAVOORI \& NOAH ARCENEAUX

978-1-4331-1300-0 | PB | \$35.95 | 978-1-4331-1301-7 | HC | \$139.95

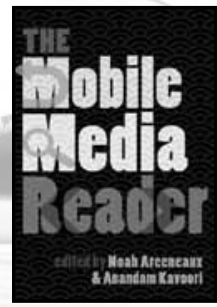

\section{BLACK STUDIES AND CRITICAL THINKING}

EDITED BY ROCHELLE BROCK \&

RICHARD GREGGORY JOHNSON III

NEW IN THIS SERIES:

READING AFRICAN AMERICAN EXPERIENCES

IN THE OBAMA ERA: THEORY, ADVOCACY, ACTIVISM

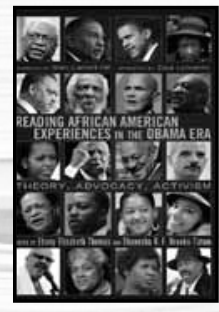

EDITED by EBONY EliZABETH THOMAS \& SHANESHA R. F.BROOKS -TATUM

978-1-4331-1125-9 | PB | \$36.95 | 978-1-4331-1128-0 | HC | \$149.95

\section{WASHINGTON COLLEGE STUDIES IN RELIGION, CULTURE, AND POLITICS \\ EDITED BY JOSEPH PRUD'HOMME \\ NEW IN THIS SERIES:}

In Search of Polin: Chasing Jewish Ghosts in Today's Poland

BY GARY S. SCHIFF | 978-1-4331-1386-4 | HC | \$85.95

\section{CRITICAL QUALITATIVE RESEARCH}

Edited by ShIRley Steinberg \& Gaile S. CANNella

NEW IN THIS SERIES:

CRITICAL QuaLITATIVE RESEARCH READER

Edited by SHirley Steingerg and Gaile S. CanNella

978-1-4331-0688-0 | PB | \$62.95 | 978-1-4331-1233-1 | HC | \$189.95

\section{AMERICAN UNIVERSITY STUDIES XIX: GENERAL LITERATURE}

NEW IN THIS SERIES:

Socialist Literature: THEORY AND PRACTICE

By Abdulla Al-Dabbagh | 978-1-4331-1673-5 | HC | \$77.95

Peter Lang Publishing

29 Broadway, 18th Floor | New York, NY 10006

[p] 800- 770-LANG [f] 212-647-7707

[w] www.peterlang.com [e] customerservice@plang.com 